\title{
Effect of paste properties as inkjet printing film and Mathematical Model to Follow the Kinetic of Wetting Phenomenon
}

DOI: $10.35530 / 1 T .069 .01 .1366$

\section{REZUMAT - ABSTRACT}

Efectul proprietăților pastei ca film de imprimare cu jet de cerneală și modelul matematic pentru urmărirea fenomenului cinetic al umectării

Imprimarea cu jet de cerneală este un tip de imprimare fără impact, având capacitatea de a produce imagini color de înaltă calitate. Aplicarea acestei proceduri este foarte delicată în ceea ce privește compoziția pastei și condițiile operative. În primul rând, acest studiu investighează morfologiile de uscare pentru filmul de acoperire utilizat în acest domeniu. A fost studiat, de asemenea, efectul compușilor filmului care sunt utilizați pe scară largă ca acoperiri funcționale în textile. Condițiile de uscare și compușii sistemului, agent de îngroșare - uree, afectează în profunzime morfologia filmului de acoperire. Mai mult, comportamentele de umectare și de impregnare sunt direct legate de compușii sistemului studiați și de aplicațiile experimentului. În final, aceste rezultate obținute sunt confirmate de comportamentul la umectare al tricoturilor din poliamidă.

Cuvinte-cheie: imprimare cu jet de cerneală, agent de îngroșare, morfologie de uscare, umectare

Effect of paste properties as inkjet printing film and Mathematical Model to Follow the Kinetic of Wetting Phenomenon

Inkjet printing is a type of non-impact printing with the ability to produce high quality color images. The application of this procedure is very delicate in term of the paste composition and the operative conditions. In this field, firstly the present paper investigates the drying morphologies for the coating film. Then, the effect of film compounds which are widely as functional coatings in textile was studied. Results show that the drying condition and the system thickener - urea compounds affect deeply the film coating morphology. Furthermore, the wetting and the impregnation behaviors are directly related to the studied system compounds and the experiment applications. Finally, these obtained results are confirmed by the wetting behavior on the knitted polyamide fabrics.

Keywords: inkjet printing, thickener, drying morphology, wetting

\section{INTRODUCTION}

Textile printing markets are changing rapidly due to demands imposed by globalisation, mass customisation, quick response, cost effectiveness and ecology. These factors have significantly influenced the global textile printing which lead to the evolution of digital printing [1-3]. Digital ink-jet printing is a non-contact printing technology. The ink droplets are produced and deposited on substrates materials in response to an electronic signal [4]. The ink-jet printing of textiles offers many potential benefits over conventional screen printing methods [5-6]. It is recognized as the best available simple technique and environmentally clean technology. The ink-jet printing technology don't need the preparation of printing screens. Therefore, the digital design can directly transferred onto the textile surface with the computer software and ink-jet printers. Then, less dye, energy and water are consumed in ink-jet than in screen printing [7-9]. In recent years, ink-jet printing has been increasingly popular due to its simple operation procedures, such as paste pre-treatment, ejected ink adjustment, steaming and washing, which facilitate control of printing quality [10].
First the fabric needs to be pre-treated prior to printing where it has to be padded with a pre-treatment paste [11-15]. Then, the print is then normally steamed to fix the dye onto the cotton fabric and then washed thoroughly to remove any unreacted dye, chemicals and thickener. The paste is usually prepared with either sodium alginate or chitosan [12, 14-15] in the presence of sodium bicarbonate and urea. These compounds print paste and process conditions have important effect on the final color design. Therefore, different factors affect the spreading, diffusion and evaporation phenomena of the ink droplet which control the design contour and the ink fixation. Several studies show the effect of the type of used thickener film in ink-jet printing process and it is demonstrated that the rheological properties of the printing pastes are principally determined by thickeners [16-18]. Therefore, the print paste rheology is a key word for printing quality, so it affects color properties. Indeed, the drying of coating substance on materials has important effect on various industrial applications such as inkjet printing [19-20]. In fact, Kagami [21-24] shows that molecules distribution of the paste solution on the substrate after drying is 
described by a power relation between the vaporization rate, the diffusion coefficient of the solvent and the concentration of the solution. Then, the morphological structures resulting from the drying conditions of 'thickener - urea' are of crucial importance as regards the wetting phenomenon. Finally, different recipe compounds and their percentage have significant effect on the ink droplet spreading. On the other hand, the steaming time after ink-jet printing, are the main factors affecting the final color yield.

In the same case of factors affecting the ink-jet printing result, the textile properties affect deeply the liquid transport in textile fabric [25]. Moreover, Fan and Kim [26-27] investigated the effect of weave of fabrics on the ink jet printing quality and they showed that the plain weave fabrics have the highest effect than the knitted one. Then, these authors have studied the effect of different treatments and used recipes on the fabric. They demonstrated that the effect of fabric structure on printing quality disappears when pretreatments are included. In the same line, Park and co-workers [28] conducted a similar study. They assessed mainly the effect of fabric structure (weave), pretreatments and ink type. They confirmed the significance of fabric structure, yarn size and hydrophilic/hydrophobic nature of the fabric.

The present study aims to fulfill and put the accent on important factors compounds and their percentages of the paste recipe on the wetting phenomenon on inkjet printing film. Then, we are interested on the drying morphology of coating paste. Finally, mathematical modeling was put in to estimate the wetting phenomenon.

\section{EXPERIMENTAL SECTION}

\section{Finishing treatment}

Before experiment setting, glass substrates $(2,5 \times 2,5$ $\mathrm{cm}^{2}$ ) were used to deposit the coating paste film in order to study its morphology and its wetting behavior. These glass plates have been cleaned previously to the ultrasonic sounds during 30 seconds in the ethanol, then rinsed with the same solvent and dried to nitrogen. Then the surface is treated and activated in an oxidizing solution "Piranha" in $50{ }^{\circ} \mathrm{C}$ during 30 min (mixture of 3 vol. of $30 \% \mathrm{H}_{2} \mathrm{O}_{2}$ and 7 vol. $\mathrm{H}_{2} \mathrm{SO}_{4}$ ), to produce highly hydrophilic surfaces. This treatment is finished by rinsing with deionised and twice distilled and then dried under flux of nitrogen. The acid coating solution was supplied from an industrial society specialized in ink-jet printing (Textile Industrial Company (ITS), Monastir - Tunisia). The characteristics of the acid coating solution were given in table 1.

The coating paste films were prepared by spin coating onto clean glass plates $\left(2.5 \times 2.5 \mathrm{~cm}^{2}\right)$ for $30 \mathrm{sec}-$ ond at an angular velocity $2000 \mathrm{rpm}$. The paste solution was prepared according to the optimal printing recipe. In order to study the effect of important compounds of the recipe, we are interested of the thickeners and the urea. Three quantities of the thickeners

\begin{tabular}{|l|l|}
\hline \multicolumn{1}{|c|}{ Compounds } & \multicolumn{1}{c|}{ Concle 1} \\
\hline Minerprimer P-INK $(\mathrm{g} / \mathrm{L})$ & 100,200 and 300 \\
\hline Urea $(\mathrm{g} / \mathrm{L})$ & 50,100 and 150 \\
\hline Setaprint NDG $(\mathrm{g} / \mathrm{L})$ & 20 \\
\hline Bicarbonate $(\mathrm{g} / \mathrm{L})$ & 45 \\
\hline
\end{tabular}

product were used (100 g/L, $200 \mathrm{~g} / \mathrm{L}$ and $300 \mathrm{~g} / \mathrm{L})$, then the effect of urea were quantified and three values were used (50 g/L, $100 \mathrm{~g} / \mathrm{L}$ and $150 \mathrm{~g} / \mathrm{L})$.

\section{Techniques of measure}

In order to study the morphology properties of different prepared coating film, thin acid coating films were observed with an optical microscope of which the fine morphological structures were obtained. For best resolution of structures, pictures were repeated 10 times. For the drying morphologies two temperatures were studied, the coating film or the coated fabric was dried at room temperature $\left(25^{\circ} \mathrm{C}\right)$ and oven conditions $\left(110^{\circ} \mathrm{C}\right)$ during 120 seconds. To quantify the wetting phenomenon, the ink droplet $(45 \mathrm{mN} / \mathrm{m})$ was used and the evolution of drop profile was captured with video-camera of GBX Digidrop with 25 captures per second. Every measure was repeated 3 times.

\section{Experimental design method}

The obtained results were analyzed using the software Minitab 15 and the main effects, interactions between factors, the regression model and response plot were determined. The general behavior of different phenomena as the spreading, the diffusion and the evaporation, can be represented by the regression model and the correlation between parameters. The choice of adequate equation which should be used is dependent of the $\mathrm{R}^{2}$-value of each model and the $p$-value tells us whether a variable has statistically significant.

Statistical approaches are the ideal means for optimization studies in industrial processes. The level and code of variables considered in this study are shown in table 2 . The concentration of the thickener, the concentration of urea and the time are selected as independent variables. The choice of these factors is approved by their important effect on the studied phenomenon.

Table 2

\begin{tabular}{|l|c|c|c|c|}
\hline \multicolumn{1}{|c|}{ Variables } & Symbols & \multicolumn{3}{c|}{ Levels } \\
\hline Concentration of thickener & CT (g/L) & 100 & 200 & 300 \\
\hline Concentration of urea & CU (g/L) & 50 & 100 & 150 \\
\hline Time & T (s) & $0,5,10,15,20$ \\
\hline
\end{tabular}

\section{RESULTS AND DISCUSSION}

\section{Effect of drying conditions}

In order to study the effect of the drying temperature on the paste coating film, two drying conditions were 


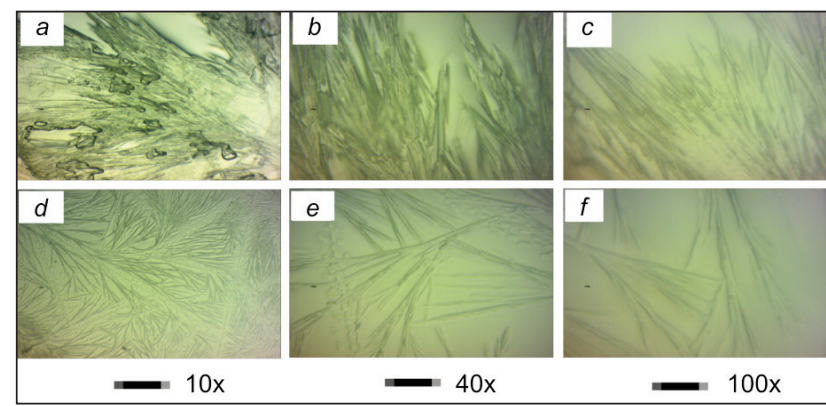

Fig. 1. Optical micrographs showing the representative morphologies resulting from the two extreme drying conditions; $a, b$ and $c$ ambient - dried $\left(22{ }^{\circ} \mathrm{C}, 30 \% \mathrm{RH}\right)$ and, $d$, $e$ and $f$ oven - dried $\left(22^{\circ} \mathrm{C}, 30 \% \mathrm{RH}\right)$

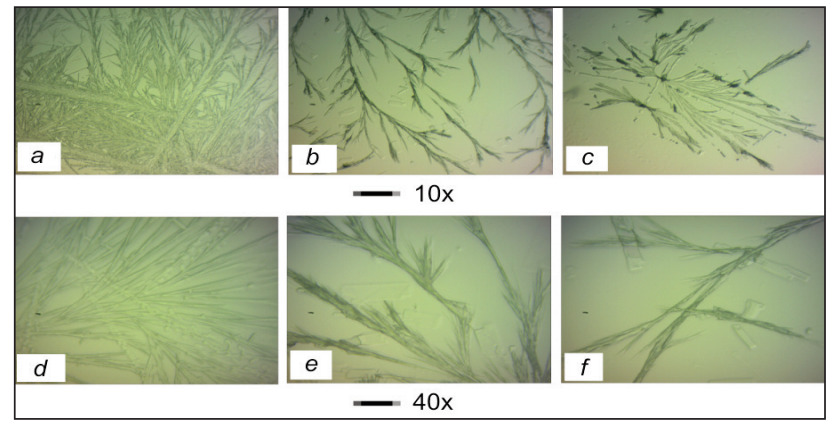

Fig. 2. Optical micrographs showing the representative morphologies of the paste recipe resulting from three living time in the oven room; $(a-d) 60$ seconds $(b-e)$ 120 seconds and $(c-f) 180$ seconds

used. The ambient drying conditions $\left(22^{\circ} \mathrm{C}, 30 \% \mathrm{RH}\right)$ and the oven drying one $\left(110^{\circ} \mathrm{C}, 2 \mathrm{~min}\right)$.

The ambient $\left(22^{\circ} \mathrm{C}, 30 \% \mathrm{RH}\right)$ and oven $\left(110^{\circ} \mathrm{C}, 2 \mathrm{~min}\right)$ drying morphologies of the coatings paste are shown in figure 1. The micrographs oven drying morphology show uniform and homogenous structure at this micrometer scale (figure $1, d$ ). But the one of the ambient drying conditions is characterized by the highly anisotropic and dense crystal, line domains composed needle - like fibrils (figure 1,a). Indeed, while increasing the temperature, the size of crystals decreases and the structure becomes more and finer and compact (figure 1,f). The coating layer becomes more uniform and homogeneous as shown in the optic microscopy. These needle-like structures (figure $1, a)$ are grown from the evaporating polar solvents. Then, this structure may be explained by the segregation of the urea phase and the residual components during the drying. Finally the morphological difference of the two drying conditions can be due to the extraction kinetics and the equilibrium residual water amount.

\section{Effect of the oven drying time}

In this paragraph the time of the oven drying conditions was analyzed. Three studied time (60 seconds, 120 seconds and 180 seconds) were used at the same oven drying temperature $110^{\circ} \mathrm{C}$.

The video-images in figure $3, a, b, c$ and $d$ show the top view of the wetting spot at first contact water drop-coating film and at the maximum spreading. The

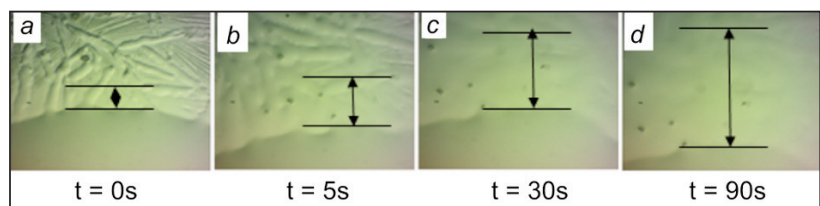

Fig. 3. Optical video-microscopy images showing the drop at different times on the thickener coating for the oven-drying conditions

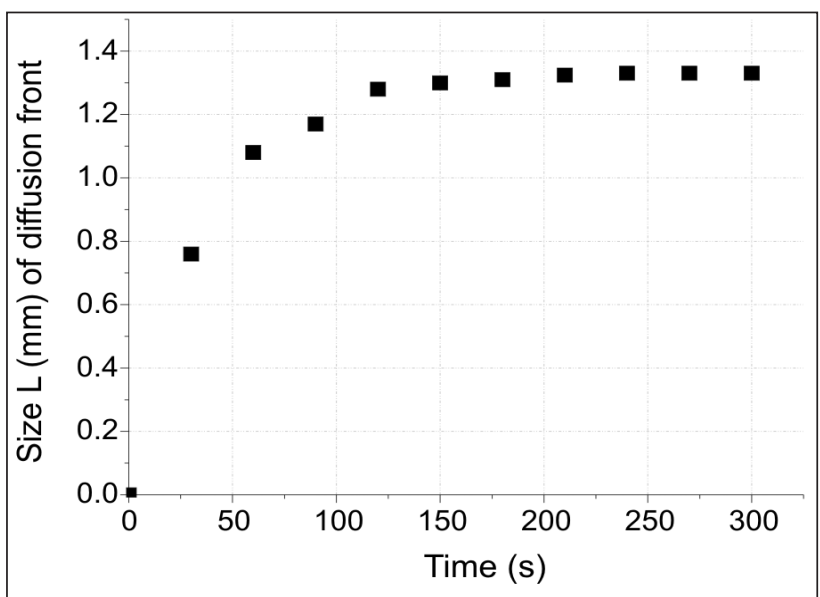

Fig. 4. Time growth of the diffusion front of the water drop on coating film at oven drying conditions

evolution of the drop profile on the oven coating film possesses axi-symmetry shape which indicates and confirms the morphological homogeneity of this coating film. This drop wetting behavior according to the drying morphology may affect the wetting phenomenon. This morphology can controls other than the drop shape, the wetting as the spreading and the diffusion of liquid into the coating film. In this case, we plotted the time growth of the diffusion front of the water drop on the oven drying coating film given by figure 4 . The drying morphology influences deeply the spreading and the diffusion of the water drop. Important spreading rate was observed for the first instants and the size $L_{e q}$ was obtained for two minutes and it's equal to $1,326 \mathrm{~mm}$. At longs time, after two minutes, this diffusion front is constant and the diffusion dominates the wetting phenomenon. The variation of the size $(L)$ of the diffusion front follows exponential distribution as given in the following equation:

$$
\left[L(t) / L_{e q}\right] \sim\left[1-\exp \left(-t / \tau_{e q}\right)\right]
$$

With $t$ is the time and $\tau_{e q}$ - the characteristic time constant of growth of the diffusion front. The diffusion front evolution show the conformity of the theory resulted which follow the classical Washburn-Rideal square-root dependence on time.

The drying conditions affects considerably the coating paste morphology and the especially the size of the diffusion front around the wetting spot as demonstrated above. Further experimental evidence towards these morphological effects are given in figure 5 , which represents the time variation of the drop profile on the glass plate, the ambient dried and oven dried 

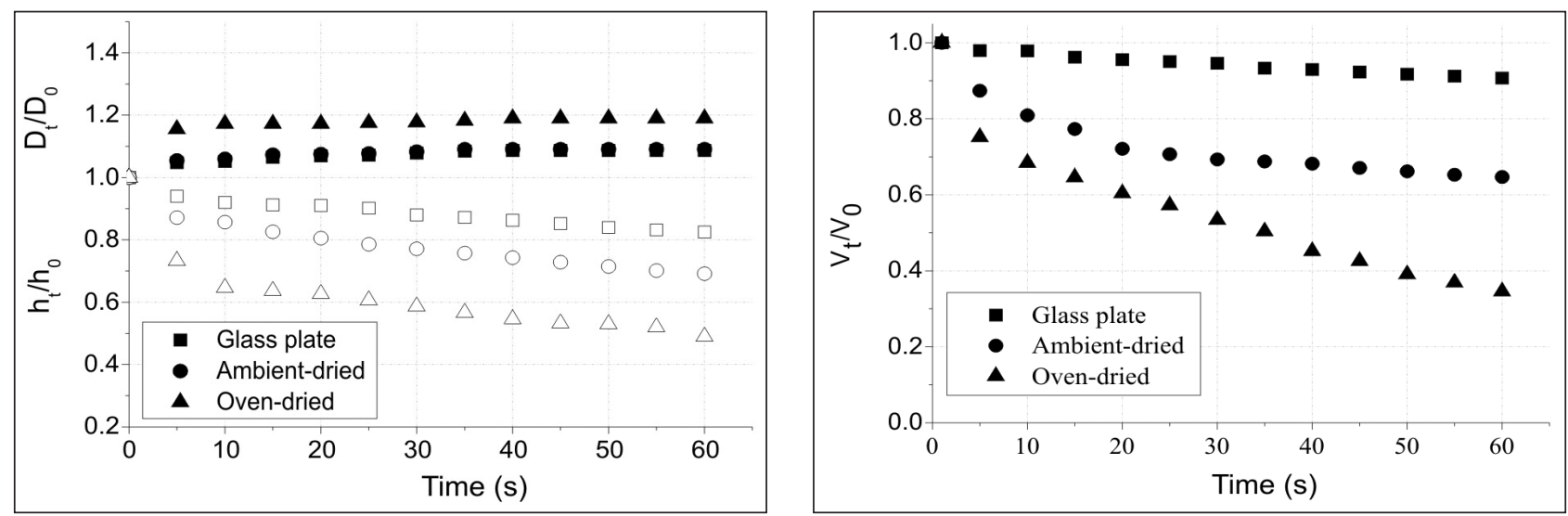

Fig. 5. Morphology-dependent wetting kinetics of the drying temperature of the coatings paste and the virgin glass plate as characterized by the time-evolution of the drop contact angle, diameter, height and the volume

coating film. From the comparison of wetting parameters (spreading, diffusion and evaporation) on used systems (drop - glass plate, drop - ambient dried film and drop - oven dried film) three phenomena were identified as the spreading, the diffusion (for the coating film) and evaporation that control the evolution of the drop profile. The profile of the drop evolves according to two distinct governments. The first is at short times until 30 seconds, which characterized by the coexistence of the spreading and evaporation. In the second left (long times) the stabilization phase was observed where the drop diameter reach its maximal spreading and stabilized. But the volume continues to decrease with slow slope. Therefore, the evaporation and the diffusion control the drop profile during this running.

Therefore, from this figure, the rate and extend of the spreading on the oven dried coating film was very larger than others used systems. But the spreading rate of the ambient dried conditions remains slightly higher than the glass plate. Thus, the thinning rate $\left(I \Delta h_{t} / \Delta t\right)$ of this wetting film is smaller than that measured on the glass plate and ambient-dried conditions. This is may be explained by the effect of the morphological structure of the coating film after drying conditions. The oven dried film possesses homogenous surface without irregularities which encourages the spreading phenomenon (axi-symmetry drop profile and the highest spreading rate) and the diffusion. The latter phenomenon can be explained that the oven-dried is susceptible to absorb more water quantities, so its dehydration level as its reabsorbing water propensity to reabsorb water is very important. Thus, this explanation can be confirmed by the important decrease of the volume for the oven dried coating film. Contrarily, the ambient dried film has the smaller thinning rate $\left(I \Delta \mathbf{h}_{\mathbf{t}} / \Delta \mathbf{t} \mathbf{l}\right)$ than the glass plate and more important compared to the oven dried film. Finally, the wetting phenomenon on the ambient dried conditions has the lower diffusion rate than the oven dried film.

\section{Effect of the paste constituent}

In this part, the effect of each constituent on the film morphology and on its wetting phenomenon was investigated. The thickener and the urea were studied. Three concentration of each component were used of the thickener and the urea respectively (100, 200 and $300 \mathrm{~g} / \mathrm{L}$ ) and (50, 100 and $150 \mathrm{~g} / \mathrm{L})$. The solutions of different composition have been smeared by 'spin coating' on glass plate and dried under oven drying condition to $110^{\circ} \mathrm{C}$ during 2 minutes, then captured with optic microscope. These drying morphologies of different studied films, as well as optic microscopy reveals it, are given in figure 6 and figure 8 . Their wetting behavior was illustrated in figure 7 and figure 9 .

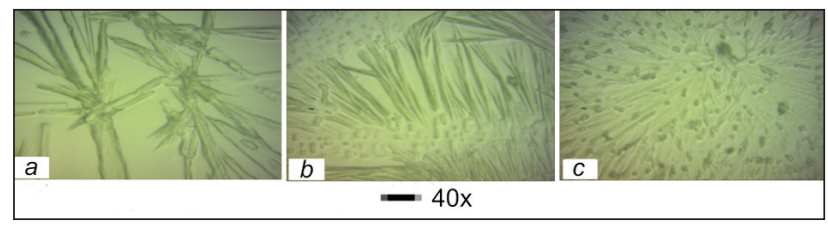

Fig. 6. Optical micrographs showing the representative morphologies resulting from three rate of thickener in the paste recipe; $a-100 \mathrm{~g} / \mathrm{L}, b-200 \mathrm{~g} / \mathrm{L}$ and

$$
c-300 \mathrm{~g} / \mathrm{L}
$$

For the coating film having the weakest concentration of the thickener possesses a structure with highly anisotropic and dense crystalline domains composed needle-like fibrils. The increasing of the concentration of thickener in the solution, the film structure stretches toward a more uniform surface. Therefore the gotten structure can be explained by two phenomena. On the one hand, the coating film structure having the weakest concentration is similar to the structure of sodium carbonate that possesses a one presenting important rate of crystallization. The size, the density and the distribution of crystals vary according to the kinetics of evaporation and nucleation-crystallization. On the other hand, this structure can be explained by a coupling or interaction between thickener-carbonate. While increasing the concentration of the thickener, we have a total dominance of the 

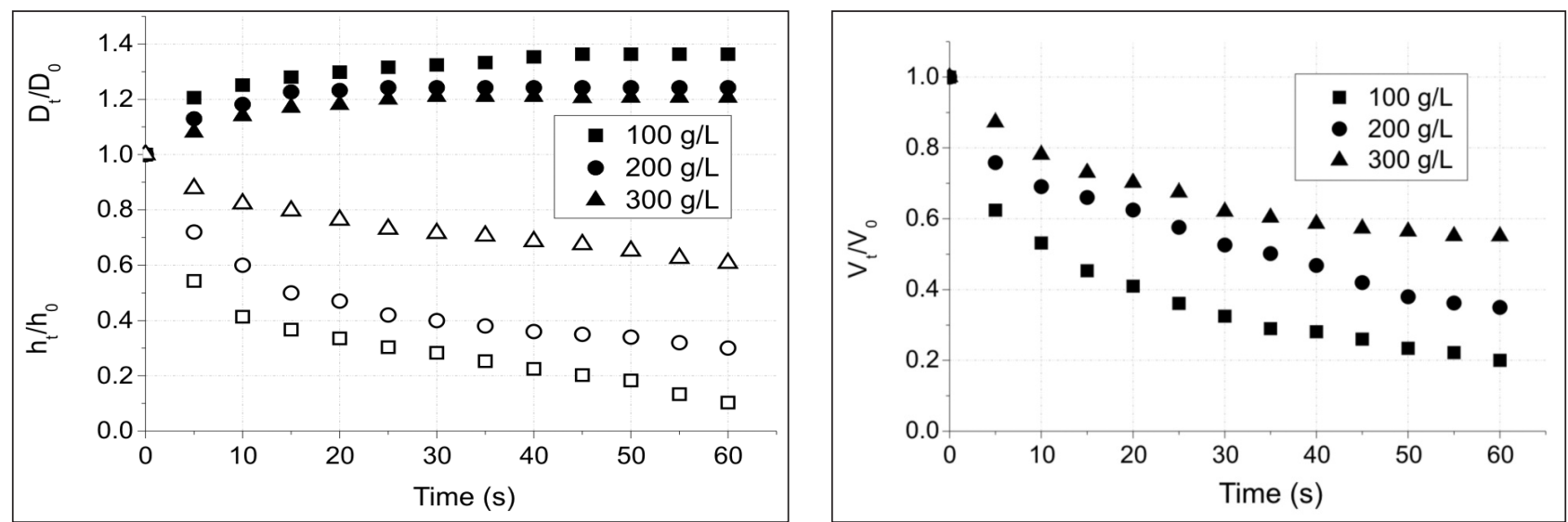

Fig. 7. Morphology-dependent wetting of the thickener coatings concentration as characterized by the time-evolution of the drop diameter, height and the volume adimensional

structure of the last constituent in relation to the one of the sodium carbonate.

The wetting kinetic of the adimensional drop height (ht/h0) and adimensional drop diameter (Dt/D0) according to different thickener concentration are plotted in figure 7 . The increasing of the thickeners concentration in the paste solution affects deeply the wetting phenomenon, especially the spreading, the diffusion and the evaporation phenomena. The wetting kinetic and the amplitude are very important for the low thickener concentration. The increase of the concentration of the thickener generates a slowing of the wetting phenomenon. Therefore important contact angle which leads to minimal spreading and diffusion for the most important thickener concentration. Then, the coating film having the important thickener concentration $(300 \mathrm{~g} / \mathrm{L})$ has the smaller thinning rate $\left(\mathbf{I} \Delta \mathbf{h}_{\mathbf{t}} / \Delta \mathrm{tl}\right)$ compared to the low one $(100 \mathrm{~g} / \mathrm{L})$. This observation was confirmed by the adimensional volume evolution which shows the important drop diffusion rate $\left(I \Delta h_{t} / \Delta t\right)$ for the coating film where we are the low thickener concentration.

Therefore, for the effect of the urea concentration, the formulation standard of the paste shows a structure presenting anisotropic surface and an elevated crystallization rate. On the other hand the increase of the

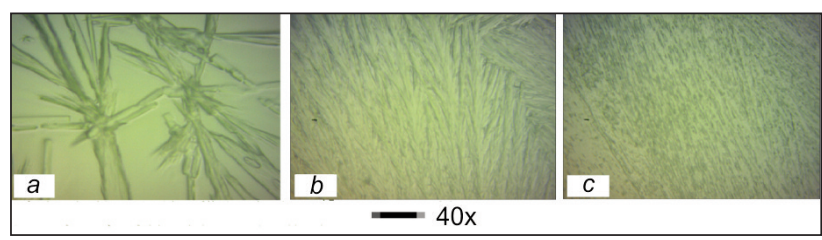

Fig. 8. Optical micrographs showing the representative morphologies resulting from three rate of urea in the paste recipe; $a-50 \mathrm{~g} / \mathrm{L}, b-100 \mathrm{~g} / \mathrm{L}$ and $c-150 \mathrm{~g} / \mathrm{L}$

urea concentration generates a film having more uniform surface. It is explained by the dominance of the sodium carbonate (figure 8) and a finer structure while increasing the urea concentration.

The effect of the urea concentration in the coating film on the drop wetting was investigated in this paragraph. Three urea concentrations were used $(50,100$ and $150 \mathrm{~g} / \mathrm{L}$ ) and others recipe constituents were constant. The figure 9 shows that the increasing of the urea concentration the amplitude of spreading remains intact. This is indicates the negligible effect of this constituent on the wetting kinetic. Therefore the evolution of the adimensional height was not affected by the urea amount variation. Then, the low variation in the adimensional volume may be explicated by the hygroscopic character of the coating film.
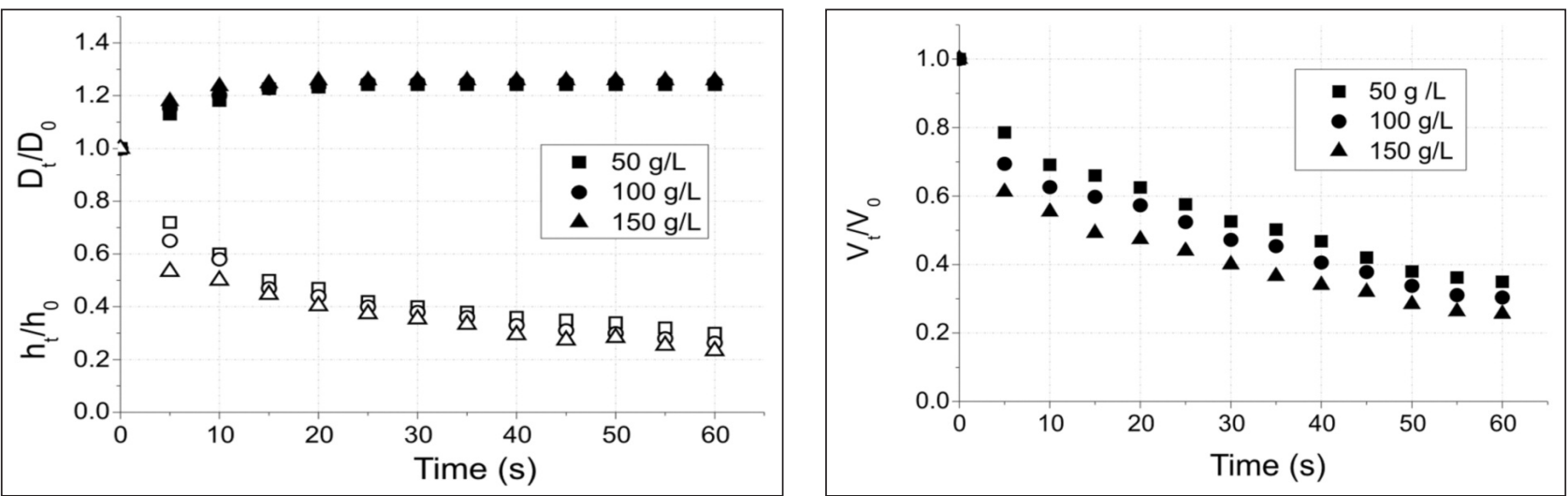

Fig. 9. Morphology-dependent wetting of the urea concentration as characterized by the time-evolution of the drop diameter, adimensional height and volume 


\section{Mathematical model}

Using Minitab software, the general behavior of the adimensional diameter can be simulated by a mathematical equation. Two types of equations can be used in order to model different responses of our study (adimensional diameter, height and volume); the linear equation (1) or the linear equation with interactions (2). Therefore, according to studied factors, different responses can be written as linear equation or linear equation with interaction as follows:

$\mathrm{D}_{\mathrm{t}} / \mathrm{D}_{0}=\mathrm{K}+\mathrm{a}_{1}$ [Thickener $]+\mathrm{a}_{2}[$ Urea $]+\mathrm{a}_{3}($ Time $)$

$\mathrm{h}_{\mathrm{t}} / \mathrm{h}_{0}=\mathrm{K}+\mathrm{b}_{1}$ [Thickener] $+\mathrm{b}_{2}$ [Urea] $+\mathrm{b}_{3}$ (Time) (1)

$\mathrm{V}_{\mathrm{t}} \mathrm{N}_{0}=\mathrm{K}+\mathrm{c}_{1}[$ Thickener $]+\mathrm{c}_{2}[$ Urea $]+\mathrm{c}_{3}$ (Time)

or,

$\mathrm{D}_{\mathrm{t}} / \mathrm{D}_{0}=\mathrm{K}_{1}+\mathrm{a}_{1}[$ Thickener $]+\mathrm{a}_{2}[$ Urea $]+\mathrm{a}_{3}($ Time $)+$

$+a_{12}$ [Thickener] $*\left[\right.$ Urea] $+a_{13}$ [Thickener] $*($ Time $)+$

$+a_{23}[$ Urea $] *$ (Time)

$\mathrm{h}_{\mathrm{t}} / \mathrm{h}_{0}=\mathrm{K}+\mathrm{b}_{1}[$ Thickener $]+\mathrm{b}_{2}[$ Urea $]+\mathrm{b}_{3}($ Time $)+$

$+b_{12}[$ Thickener $] *[$ Urea $]+b_{13}[$ Thickener $] *($ Time $)+$

$+\mathrm{b}_{23}$ [Urea] $*$ (Time)

$\mathrm{V}_{\mathrm{t}} / \mathrm{V}_{0}=\mathrm{K}+\mathrm{c}_{1}[$ Thickener $]+\mathrm{c}_{2}[$ Urea $]+\mathrm{c}_{3}($ Time $)+$

$+\mathrm{C}_{12}$ [Thickener] $*[$ Urea $]+\mathrm{C}_{13}[$ Thickener $] *($ Time $)+$

$+\mathrm{C}_{23}[$ Urea $] *$ (Time)

The results obtained for this study shows that only the regression linear terms in the model were significant and the interactions in the regression model were no significant. To evaluate the significance of each variable, the p-values lower than 0.05 indicate that the terms and the model are statistically significant. Table 3 consists of ANOVA analyze of variance of the regression model. The $p$-value, equal to zero, shows that the linear regression is very significant. Therefore, the equation of linear model without interactions was chosen to reproduce the mathematical model of the adimensional diameter, height and the volume.

The statistical technique is used to investigate and model the relationship between the response variable and the independent input factors. The model of the diameter adimensional or spreading rate $\left(D / D_{0}\right)$ is detailed in this paragraph. The input factors are the Concentration of the Thickener (CT), the Concentration of the Urea (CU) and the Time (T). These factors were evaluated by using factorial design where the main effects, interaction plot and the contour of surface of response were investigated. Main effects and the of the adimensional diameter are plotted in figure 10. The effect of the spreading phenomenon duration (time) is more important than other factors. The thickener concentration is less influential on the adimensional diameter $\left(D_{t} / D_{0}\right)$. Finally, the amount of used urea has the less effect on the drop diameter variation. It is to highlight that the time and the urea concentration have positive effect, contrarily to the quantity of thickener which has negative effect on the drop spreading phenomenon.

The study of the diagram of interactions plotted in figure 11 show parallel lines. While passing from level to

\begin{tabular}{|c|c|c|c|c|c|c|}
\hline \multicolumn{7}{|c|}{ ANOVA for the adimensional diameter $D_{t} / D_{0}$} \\
\hline Source & DF & Seq SS & Adj SS & Adj MS & $\mathrm{F}$ & $\mathrm{P}$ \\
\hline Regression & 6 & 0,408362 & 0,408362 & 0,068060 & 28,90 & 0,000 \\
\hline Linear & 3 & 0,397767 & 0,052690 & 0,017563 & 7,46 & 0,000 \\
\hline Interaction & 3 & 0,010595 & 0,010595 & 0,003532 & 1,50 & 0,230 \\
\hline Residual error & 38 & 0,089496 & 0,089496 & 0,002355 & & \\
\hline Total & 44 & 0,497858 & & & & \\
\hline \multicolumn{7}{|c|}{ ANOVA for the adimensional height $h_{t} / h_{0}$} \\
\hline Source & DF & Seq SS & Adj SS & Adj MS & $\mathrm{F}$ & $\mathrm{P}$ \\
\hline Regression & 6 & 1,91880 & 1,918796 & 0,319799 & 27,49 & 0,000 \\
\hline Linear & 3 & 1,79348 & 0,379366 & 0,126455 & 10,87 & 0,000 \\
\hline Interaction & 3 & 0,12531 & 0,125314 & 0,041771 & 3,59 & 0,062 \\
\hline Residual error & 38 & 0,44202 & 0,442023 & 0,011632 & & \\
\hline Total & 44 & 2,36082 & & & & \\
\hline \multicolumn{7}{|c|}{ ANOVA for the adimensional volume $\mathrm{V}_{\mathbf{t}} / \mathrm{V}_{0}$} \\
\hline Source & DF & Seq SS & Adj SS & Adj MS & $\mathrm{F}$ & $\mathrm{P}$ \\
\hline Regression & 6 & 1,30688 & 1,306885 & 0,217814 & 26,26 & 0,000 \\
\hline Linear & 3 & 1,23491 & 0,228613 & 0,076204 & 9,19 & 0,000 \\
\hline Interaction & 3 & 0,07198 & 0,071979 & 0,023993 & 2,89 & 0,050 \\
\hline Residual error & 38 & 0,31520 & 0,315200 & 0,008295 & & \\
\hline Total & 44 & 1,62208 & & & & \\
\hline
\end{tabular}




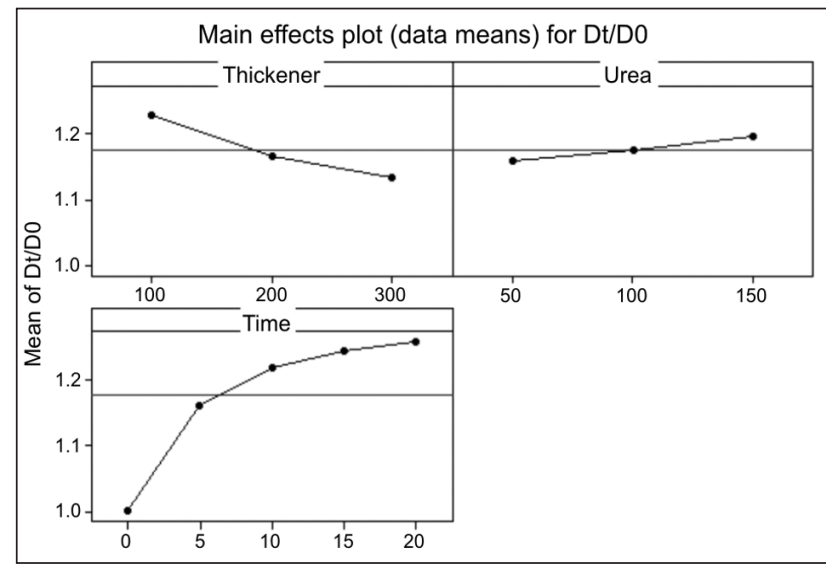

Fig. 10. Main effects diagrams for adimensional diameter at different factor

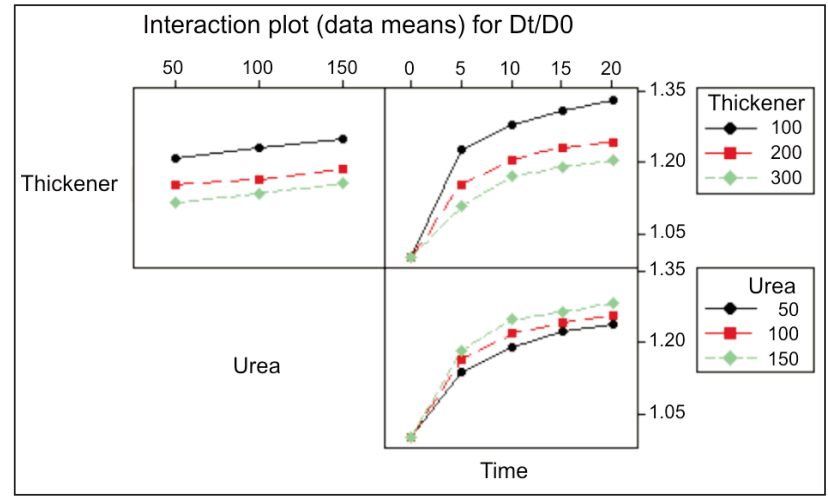

Fig. 11. Interactions diagrams for adimensional diameter at different factor

another negligible interaction was observed this is in coincidence with results obtained in table 3 . The regression equation is:

$$
\begin{gathered}
D t / D 0=1,11-0,000471[E p]+0,000375[U r]+ \\
0,0119 T
\end{gathered}
$$

Table 4

\begin{tabular}{|l|c|c|c|c|}
\hline Predictor & Coef & SE coef & T & P \\
\hline Constant & 1,11344 & 0,02853 & 39,03 & 0,000 \\
\hline$[\mathrm{Ep}]$ & $-0,00047100$ & 0,00009021 & $-5,22$ & 0,000 \\
\hline$[\mathrm{Ur}]$ & 0,0003753 & 0,0001804 & 2,08 & 0,004 \\
\hline $\mathrm{T}$ & 0,011938 & 0,001042 & 11,46 & 0,000 \\
\hline
\end{tabular}

$\mathrm{R}-\mathrm{Sq}=98,9 \%$

Table 5

\begin{tabular}{|l|c|c|c|c|c|}
\hline \multicolumn{1}{|c|}{ Source } & DF & SS & MS & F & P \\
\hline Regression & 3 & 0,39777 & 0,13259 & 54,31 & 0,000 \\
\hline Residual Error & 41 & 0,10009 & 0,00244 & & \\
\hline Total & 44 & 0,49786 & & & \\
\hline
\end{tabular}

As shown in the table, all factors are statistically significant ( $p$-value of the constant was equal to 0.000 , $p$-value of the CT factor was equal to $0.000, p$-value of the $\mathrm{CU}$ was equal to $0.004<<0.05$ and $p$-value of the $T$ was equal to 0.000 ). The regression linear model obtained by Minitab software for the diameter is very significant $(p=0.000)$ as demonstrated in the ANOVA (table 5). The regression model of the adimensional diameter is given by the following equation: The obtained components of the drop spreading diameter model show positive sign and the Time ( $T$ ) has the important constant coefficient in the equation. These observations are in coincidence with the main effects diagram.

Then, we are interested to important shutter of this study. We are attracted to application and development of the response surface method design for finding regions where there is an improvement in response and then the optimum response desired by the industrial. Figure 12 point up the contour plots which show contour lines of Concentration of the Thickener [CT] and the one of (DT) the Urea [CU] factors of the diameter. Results of the contour of the response surface showed in the variation of the diameter demonstrates that in the first time,

Then, of the same manner of the diameter, we are interested to the other wetting parameters as the height and volume. The obtained results are given in

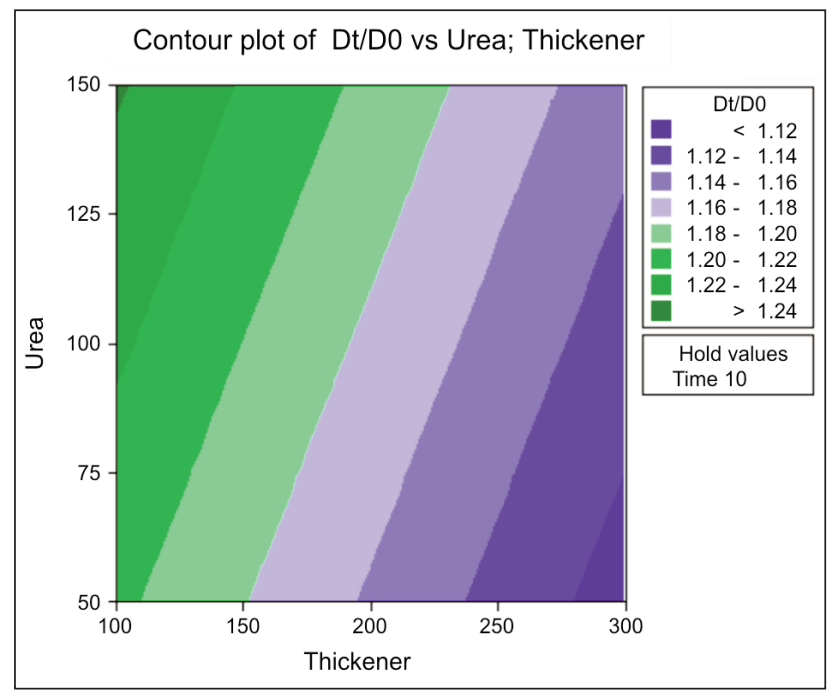

Fig. 12. Contour plot of D/D0 versus Concentration of the thickener and the concentration of the urea

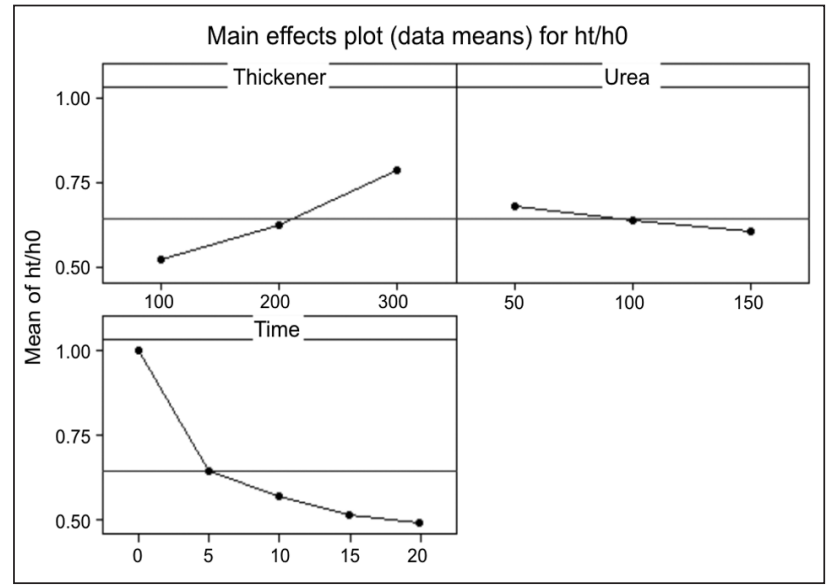

Fig. 13. Main effects for adimensional height at different factor 


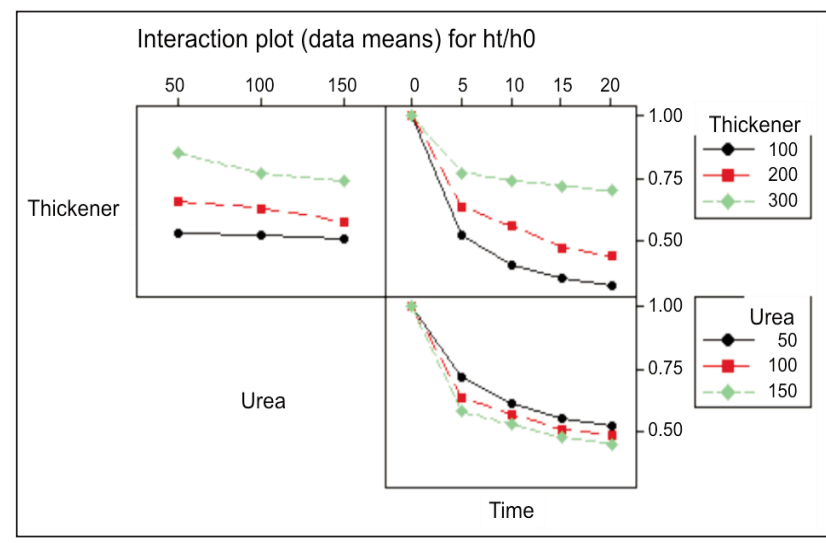

Fig. 14. Interactions diagrams for adimensional height at different factor

equations (ht/h0) and their confirmations are shown in table 6.

The regression equation is

$$
\begin{gathered}
h t / h 0=0,678+0,00135[E p]-0,000740[U r]- \\
0,0232 T
\end{gathered}
$$

Table 6

\begin{tabular}{|l|c|c|c|c|}
\hline Predictor & Coef & SE coef & T & P \\
\hline Constant & 0,67842 & 0,06791 & 9,99 & 0,000 \\
\hline$[\mathrm{Ep}]$ & 0,0013450 & 0,0002147 & 6,26 & 0,000 \\
\hline$[\mathrm{Ur}]$ & $-0,0007400$ & 0,0004295 & $-1,72$ & 0,002 \\
\hline $\mathrm{T}$ & $-0,023153$ & 0,002480 & $-9,34$ & 0,000 \\
\hline
\end{tabular}

$\mathrm{R}-\mathrm{Sq}=99 \%$

Table 7

\begin{tabular}{|l|c|c|c|c|c|}
\hline \multicolumn{1}{|c|}{ Source } & DF & SS & MS & F & P \\
\hline Regression & 3 & 1,78995 & 0,59665 & 43,13 & 0,000 \\
\hline Residual error & 41 & 0,56718 & 0,01383 & & \\
\hline Total & 44 & 2,35713 & & & \\
\hline
\end{tabular}

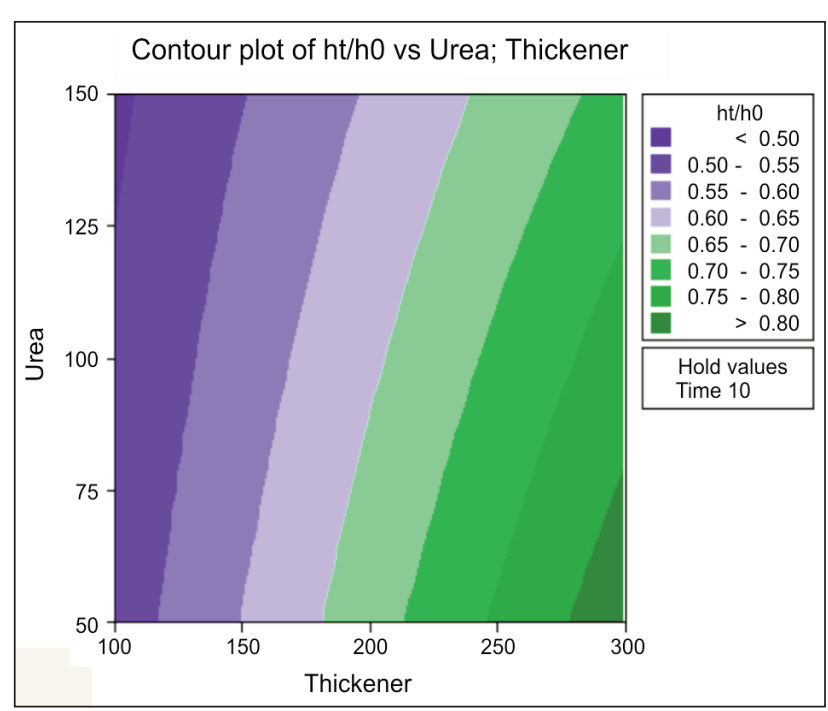

Fig. 15. Contour plot of ht/h0 versus concentration of the thickener and the concentration of the urea

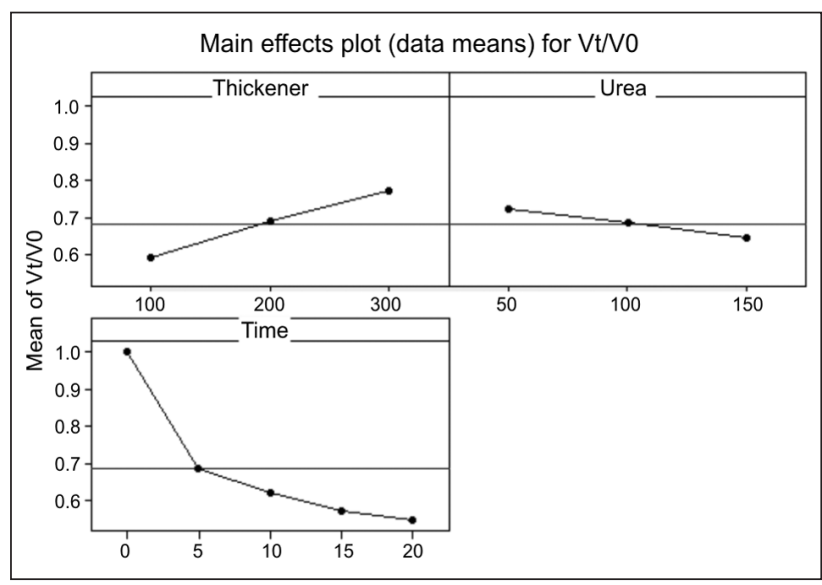

Fig. 16. Main effects for adimensional volume at different factor

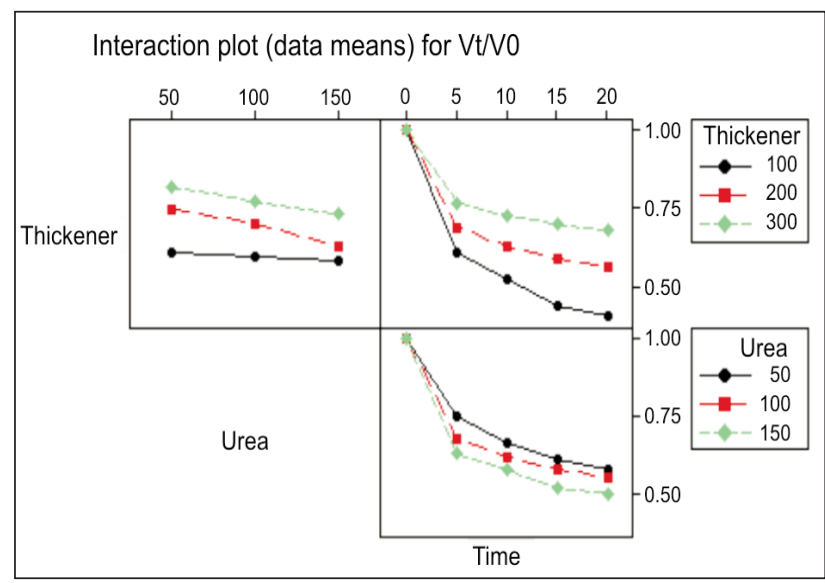

Fig. 17. Interactions diagrams for adimensional volume at different factor

The regression equation is

$V t / V 0=0,785+0,000908[E p]-0,000772[U r]-$ $0,0205 T$

Table 8

\begin{tabular}{|l|c|c|c|c|}
\hline Predictor & Coef & SE coef & T & P \\
\hline Constant & 0,78520 & 0,05608 & 14,00 & 0,000 \\
\hline$[E p]$ & 0,0009083 & 0,0001773 & 5,12 & 0,000 \\
\hline$[U r]$ & $-0,0007720$ & 0,0003547 & $-2,18$ & 0,035 \\
\hline T & $-0,020500$ & 0,002048 & $-10,01$ & 0,000 \\
\hline
\end{tabular}

$\mathrm{R}-\mathrm{Sq}=96,2 \%$

Table 9

\begin{tabular}{|l|c|c|c|c|c|}
\hline \multicolumn{1}{|c|}{ Source } & DF & SS & MS & F & P \\
\hline Regression & 3 & 1,23778 & 0,41259 & 43,73 & 0,000 \\
\hline Residual error & 41 & 0,38686 & 0,00944 & & \\
\hline Total & 44 & 1,62464 & & & \\
\hline
\end{tabular}

\section{CONCLUSIONS}

There are many complex parameters that affect characteristics of digitally printed fabrics. This paper 


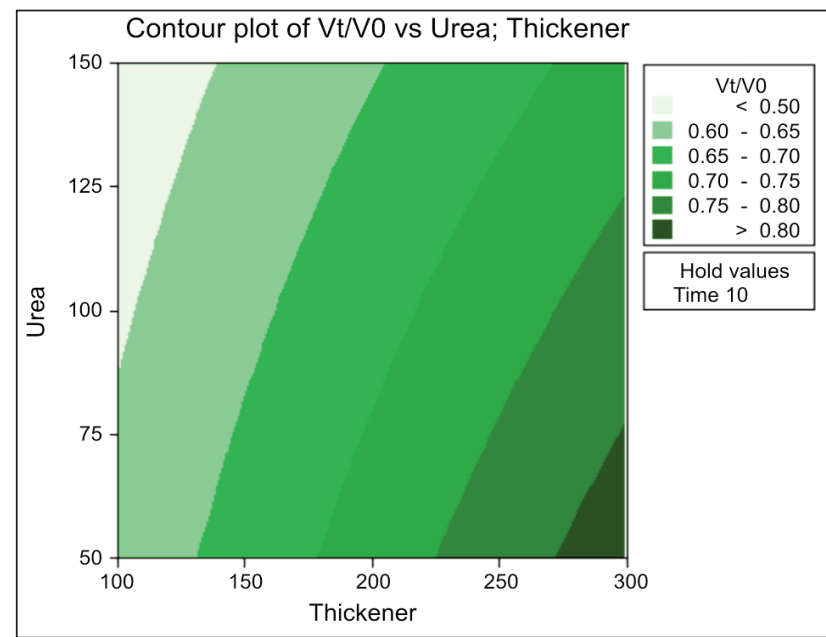

Fig. 18. Contour plot of Vt/V0 versus Concentration of the thickener and the concentration of the urea focused on the effect of film compositions on ink wetting behavior. Findings show that the drying conditions and the paste compounds affect deeply the coating film morphologies and crucially their wetting and impregnation behaviours. First, the drying conditions influence the surface morphology, therefore, especially the spreading rate. Then, the increasing of the thickener and the urea concentrations control the coating film morphology and its surface uniformity. Therefore, the thickener affects the wetting kinetic but the effect of the urea concentration on this phenomenon remains limited. Finally, the mathematical model obtained for this phenomenon is coincident with experimental results. Then, it allows us to quantify and to control various phenomena of the wetting process such as the spreading, the diffusion, the impregnation and the evaporation.

\section{BIBLIOGRAPHY}

[1] Mikuz, M., Turk, S.S. and Tavcer, P.F. Properties of ink-jet printed, ultravioletcured pigment prints in comparison with screen-printed, thermo-cured pigment prints, In: Society of Dyers and Colourists, Coloration Technology, 2010, vol. 126, pp. 249-255.

[2] Van Parys, M. The future printing will be digital, 2002, In: Melliand Textilberichte/International Textile Reports (Eng. Ed.), 83(6), E96.

[3] Gupta, S. Ink-jet printing - a revolutionary ecofriendly technique for textile printing, In: Indian Journal of Fibre \& Textile Research, 2001, vol. 26(1\&2), pp. 156-161.

[4] Gregory, P. Ink jet printing on textiles, in textile ink jet printing - A review of ink jet printing of textiles, including ITMA 2003, (T. L. Dawson and B. Glover, Eds.); In: Society of Dyers and Colourists, Technical Monograph, 2004, pp. 69-97.

[5] Choi, P.S., Yuen, C.W.M., Ku S.K.A. and Kwan, C.W. Ink-jet printing for textiles, In: Textile Asia, 2003, vol. 34 (10), pp. 21-24.

[6] Byrne, C. Textile ink jet printing-market information, potential outlets and trends, In: Textile Ink Jet printing - A review of ink jet printing of textiles, including ITMA 2003, (T. L. Dawson and B. Glover, Eds.). In: Society of Dyers and Colourists Technical Monograph, 2004, pp. 30-37.

[7] Dawson, T.L. Ink-jet printing of textiles under the microscope. In: Journal of the Society of Dyers and Colourists, 2000. Vol. 116, pp. 52-59.

[8] Mikuz, M., Sostar-Turk S. and Pogacar, V. Fibres Textiles, In: Eastern Europe, 2005, vol. 13 6(54), pp. $79-84$.

[9] Zhang, Y., Westland, S., Cheung, V., Burkinshaw S.M. and Blackburn, R.S. A custom ink-jet printing system using a novel pretreatment method, In: Coloration Technology, 2009, vol. 125(6), pp. 357-365.

[10] Ervine, S., Siemensmeyer, K., Siegel, B. A simple, universal approach to ink jet textile fabrics, In: Textile Chemist and Colorist and American Dyestuff Reporter, 2000, vol. 32(10), pp. 26-27.

[11] Fan, Q., Kim, Y.K., Lewis, A.F. and Perruzi, M.K. Fabric pretreatments and digital textile print quality, In: Journal of Imaging Science and Technology, 2003, vol. 47, pp. 400-407.

[12] Yuen, C.W.M., Ku, S.K.A., Kan, C.W. and Choin, P.S.R. Study of factors influencing color yield of an ink-jet printed cotton fabric, In: Coloration Technology, 2004, vol. 120, pp. 320-325.

[13] Yuen, C.W.M., Ku, S.K.A., Choin, P.S.R. and Kan, C.W. The effect of the pretreatment print paste contents on color yield of an ink-jet printed cotton fabric, In: Fibers and Polymers, 2004, vol. 5, pp. 117-121.

[14] Yuen, C.W.M., Ku, S.K.A., Kan, C.W. and Choin, P.S.R. Enhancing textile ink-jet printing with chitosan, In: Coloration Technology, 2007, vol. 123, pp. 267-270.

[15] Yuen, C.W.M., Ku, S.K.A., Kan and Kan, C.W. Use of biomaterial as a thickener for textile ink-jet printing, In: Journal of Applied Polymer Science, 2008, vol.107, pp. 1057-1065.

[16] Bahmani, S.A., East, G.C. and Holme, I. The application of chitosan in pigment printing, In: Journal of the Society of Dyers and Colourists, 2000, vol. 116(3), pp. 94-100.

[17] Abou-Okeil, A. and Hakeim, O.A. Effect of metal ion binding of chitosan on the printability of pretreated wool fabric, In: Coloration and Technology, 2005, vol. 121(1), pp. 41-44.

[18] Choin, P.S.R., Yuen, C.W.M., Ku, S.K.A. and Kan, C.W. Digital ink-jet printing for chitosan-treated cotton fabric, In: Fibers and Polymers, 2005, vol. 6(3), pp. 229-234. 
[19] de Gans, B.J. and Schubert, U.S. Inkjet printing of well-defined polymer dots and arrays, In: Langmuir, 2004, vol. 20, pp. 7789-7793.

[20] Soltman, D. and Subramanian, V. Inkjet-printed line morphologies and temperature control of the coffee ring effect, In: Langmuir, 2008, vol. 24, pp. 2224-2231.

[21] Kagami, H. Thickness control of a thin film after drying through thermal and evaporative management in drying process of a polymer solution coated on a flat substrate: application of the dynamical model of the drying process, In: The Proceeding of SPIE., 2011, 8068, 806813-1 - 6.

[22] Kagami H. and Kubota, H. A dynamical model of drying process of a polymer solution having plural solvents and plural solutes (polymers) coated on a flat substrate for a flat and homogeneous polymer film fabrication, In: Physica Status Solidi, (C) Current Topics in Solid State Physics, 2011, vol. 8(2), pp. 586-588.

[23] Kagami, H. More minute thickness control of a thin film after drying through temperature, evaporation and concentration management in drying process of a polymer solution coated on a flat substrate, In: Proceedings of the 19th International Drying Symposium, Lyon, August 24-27, 2014, ISBN 978-2-7598-1631-6.

[24] Kagami, H. Impact of the Marangoni effect on the thin film thickness profile after drying polymer solution coated on a flat substrate, In: Journal of the Physical Society of Japan; Conferences Proceeding, 2014b, 1, 015087-1 - 5.

[25] Achour, N.S., Baffoun, A., Hamdaoui, M. and Nasrallah. S.B. Effect of knitted parameters on wicking behaviours, In: Industria Textila, 2016, vol. 67 (2), pp. 99-102.

[26] Fan, Q., Kim, Y.K., Lewis, A.F. and Perruzzi, M.K. Effects of pretreatments on print qualities of digital textile printing, In: NIP 18, International Conference on Digital Printing Technologies, 2002, pp. 236-241, San Diego, CA, USA.

[27] Q Fan, Q., Kim, Y.K., Lewis, A.F. and Perruzzi, M.K. Fabric pretreatment and digital textile print quality. In: Journal of Imaging Science and Technology, 2003, vol. 47, p. 400.

[28] Park, H., Car, W.W., OK, H. and Park, S. Image quality of inkjet printing on polyester fabrics, In: Textile Research Journal, 2006, vol. 76, pp. 720-728.

Authors:

\section{ZOUHAIER ROMDHANI ${ }^{1,2}$ \\ MOHAMED HAMDAOUI ${ }^{2}$ \\ AMAL CHEBIL ${ }^{2}$ \\ MUSTAPHA JENDOUBI ${ }^{3}$}

${ }^{1}$ Laboratory of Interfaces and Advanced Materials (L.I.M.A),

Faculty of Sciences of Monastir - University of Monastir - Tunisia

${ }^{2}$ Textile Materials and Process Research Unit, University of Monastir - Tunisia

${ }^{3}$ Textile Industrial Company (ITS), Monastir - Tunisia

e-mail: romdhanizouhaier@gmail.com, hamdaouimohamed@yahoo.fr, ammoulachebil@gmail.com

Corresponding author:

AMAL CHEBIL

e-mail: ammoulachebil@gmail.com 